To cite this article: Blessing E. Ahaiuzu, Chidaka O. Nyemezu and Onyema Nsirim (2020) Assessment of ICT Skills of LIS Educators for the Adoption of Blended Learning in Rivers State, Nigeria. Information Impact: Journal of Information and Knowledge Management, 11:3, 51-62, DOI: dx.doi.org/10.4314/iijikm.v11i3.6

To link to this article https://dx.doi.org/10.4314/iijikm.v11i3.6

\title{
Assessment of ICT Skills of LIS Educators for the Adoption of Blended Learning in Rivers State, Nigeria
}

\author{
${ }^{1}$ Blessing E. Ahaiuzu ${ }^{1}$ Chidaka O.Nyemezu and ${ }^{2}$ Onyema Nsirim \\ ${ }^{1}$ Department of Library and Information Science, Rivers State University \\ ${ }^{2}$ Department of Library and Information Science, Ignatius Ajuru University of Education, Port-Harcourt
}

\begin{abstract}
The study assessed ICT skills of Library and Information Science (LIS) educators for the adoption of Blended Learning in Rivers State. The study adopted a descriptive survey design, with a population of 45 ; census sampling technique was adopted to sample all the 45 library educators in four library schools in Rivers. A structured questionnaire was used to gather data for the study. 42 copies of the instrument were returned and found valid for analysis. The data collected were analyzed using mean scores and simple percentages. The findings revealed that despite the fact that LIS educators could use basic computer interfaces, mobile and new media technologies for blended learning, they were not adopting blended learning. The challenges were attributed to lack of facilities, lack of skills and lack of policy. It was therefore, recommended among other things that Librarians' Registration Council of Nigeria should formulate a policy that will motivate and guide the use of blended learning in LIS education and LIS educators should acquire skills to exploit blended learning.
\end{abstract}

Keywords ICT Skills, LIS Educators, Blended Learning, Rivers State

CONTACT Ahaiuzu,B.E.,Nyemezu,C.O.and Nsirim,O nsirimonyema@gmail.com. Department of Library and Information Science, Rivers State University and Department of Library and Information Science, Ignatius Ajuru University of Education, Port-Harcourt. 2020 The Authors Published with License by Information Impact 


\section{Introduction}

Educational system has been influenced greatly by the emergence and widespread of information and communication technologies (ICTs). This significant change is being leveraged by individuals, organizations and institutions. Library and Information Science Education (LISE) has witnessed unprecedented changes due to the development and proliferation of ICTs as well as its opportunities offered. Library educators are now required to apply instructional materials in teaching and learning as the talk- chalk-board is becoming boring and students are finding it difficult to retain a long talk by a teacher. To overcome this, a system that could merge both traditional and instructional or e-learning which is blended learning emerged. The term blended learning as stated by Sen and Sarmah (2014) is not a new concept, but a recent addition to the lexicon of the education profession. They further noticed that with the rise of technological and pedagogic advances, a lot of things which can be included in the blend came into focus. Blended learning is the integration of educational technologies in teaching and learning process or simply in education in which both the educator or instructor and the student must participate. According to Chew, Jones and Turner (2008) 'blended learning involves the combination of two fields of concern: education and educational technology". It is as a 'learning system that brings together face-toface instruction with computer-mediated instruction. It has the capability of not only to bridges pace, but also to bridge time via recording, and to individualize learning by making students be in charge over their path through the material, and over the pace of learning (Bryan \& Volchenkova, 2016). This could be because blended learning according to Adebayo, Iwu-James, Olawoyin, and Fagbohun (2019) enhances the outcome of learning, flexibility for both students and teachers, improve their independence, thinking, and study skills, reduces students' withdrawal rate, foster a professional learning environment and reduces study time for the students and teachers.

Agarwal (2015) warns that the adoption of blended learning is inevitable as students will increasingly be engaged in experiential and interactive learning. Students will continue to learn from themselves and their environment just as much as they would learn from their professors and predicting the need for a blended approach to learning, more also discovered that more learners would need to have a medium that will allow them discover concepts and facts on their own which blended learning can achieve (Omiunu, 2017).Blended learning has become an emerging and prominent delivery mechanism and approach to course design in higher education. The core interest in blended learning lies in the need to provide more engaged learning experiences with recognizing the potential of the Internet and ICT (Rajkoomar, 2013). The importance of blended learning in educational system cannot be overstated however; to fully exploit the benefits of blended learning, ICT skills are required. Therefore, librarians should have the required skills to incorporate information literacy skills into course work to achieve students' learning outcomes and strive to be proficient users of instructional technologies. Adebayo, IwuJames, Olawoyin, \& Fagbohun (2019) have blamed the factors militating against the adoption of blended learning in education on lack of ICT skills. Yamada (2015) confirmed it by stating that graduates produced from developing countries also lack the needed innovation to harness and compete in a rapidly changing scientific and technological world. However, students in developing countries according to Adebayo, Iwu-James, Olawoyin, \& Fagbohun (2019) are high technology enthusiasts and are increasingly using ICTs especially mobile devices. Lippincott (as cited in Dhiman, 2010:4) asserted that:

"Librarians somewhere have found to developing web based modules to support course integrated instruction session, encourage students to actively follow the librarians' presentation using their own topics for selected searches. Students receive immediate feedbacks on search strategies during the session and can return at any time to refresh their skills for subsequent assignments. 
Librarians may use the material to guide students in using information resources specific to their assignment. This blended approach to information literacy offers students and instructors with an ability to address diverse learning styles and encourage active participation along the presentation to a $24 / 7$ access that may foster increased student contact with the librarians"

LIS educator must have knowledge and skills for handling information technology and the skills for creation and collection of information using the Internet (Hundu \& Anaele as cited in Babalola, Tsado, Udoudoh, Uno \& Madaki). Doyle (2019) added that online collaboration skills, email management skills, online research skills, desktop publishing, word processing skills, social media management, and internet search skills are skills required by library staff. Kumar (2017) included communication technology such as emails, voicemail, telephone, fax, video conferencing and internet. LIS educators should aim at undertaking instruction, research and service programmes that meet current and emerging Library information Technology needs (Muthu et.al,.2015). Skills like basic computer skills such as page formatting, using computer to access the internet and post contents online; mobile technology skills such as the use of mobile devices to download and upload documents, use of mobile devices in e-learning and for interaction with students; new media technology such as the use of Google Doc to collaborate with students, the use of One Drive to save documents to the cloud and the use of social media tools such as Facebook, Whatsapp, Telegram, Zoom to collaborate with students as well as use the media to deliver lectures

Library and information Science is an interdisciplinary study characterized with ICT especially in the present information driven era. Creativity and innovation in knowledge sharing among LIS educators is all about discovering new ways of impacting knowledge. The adoption of blended learning in LIS education is not unconnected with the challenges facing higher education in Nigeria especially in the area of diversity of the student body, cost efficiency, achieving measurable outcomes, the potential of new and advanced technologies to provide personlised learning as against the traditional method. It could also be connected to the statement credited to Rajkoomar (2013:2) that 'technology pervades almost every sphere of life from home to work to play and also has great implications for teaching and learning making the Net generation students learn in different methods than the traditional students as well as the challenge of educators to meet the needs of the Net generation is daunting'. According to Alonge (2018), over the years, LIS departments, teachers and students have adopted emerging technologies in order to introduce the best practices in teaching and learning methods and application in LIS education. He further explained that unlike before, the LIS sector is deeply rooted in digital technologies, which has led to changes in curriculum content as well as in methods of teaching and learning. Furthermore, Blended learning has mushroomed and has attracted considerable attention calling for blending of traditional face to face method and online learning method. In Nigeria, LIS education prior to the establishment of Library and Information Science Department, those who aspired to become librarians went to Britain to qualify for Association of Library Association (ALA) but for the attainment of independence in 1960, the country witnessed the establishment of tertiary institutions at various levels. Hence, the first Library school was established at University College Ibadan in 1960 (Saleh, 2012).

In Rivers State, the study of Library and Information Science started in University of Port Harcourt in 1987 as a Sandwich programme offering Diploma in Library and Information Science and Captain Elechi Amadi Polytechnic, Port Harcourt the then College of Arts and Science in the year 2004. However, the Department of Library and Information Science started to offer Bachelor's degree in University of Port Harcourt in 2015 followed by the Rivers State University in 2016 and Ignatius Ajuru 
University of Education in 2017 respectively. In expanding the frontiers of knowledge in digital age, LIS educators have been striving to apply ICT tools in library and information education. Currently, there has been an improvement in the application of modern technologies in LIS education in Nigeria. Application of ICTs in Library and information services are now being embedded in LIS curriculum to prepare students for emerging technologies in library and information science such as blended learning but this adoption may not be fully utilised if LIS educators lack prerequisite skills to adopt blended learning

\section{Statement of the Problem}

Classroom teaching though remains the dominant mode of teaching and learning in the higher education setting where students will have to rely only on lecturers for study. This traditional method is already adopted and adapted by students and lecturers. However, with the emergence of ICT, institutions are beginning to adopt several methods to complement the traditional learning which restricts educators and students to continue their teaching and learning beyond the four walls of institutions. To achieve this, online learning management systems have been adopted globally. However, due to lack of state of the art infrastructure in institutions in Nigeria, educators are considering easier means of combining both the traditional and online learning. This includes the use of online video conferencing technologies such as Zoom, Google meet, virtual classrooms, new media technologies such as Facebook, Whatsapp, GoogleDoc and Twitter. Despite these easier means of adopting blended learning, the traditional method is still dominant. This could be attributed to lack of ICT skills. Skills such as basic computer skills, mobile technology skills and new media technology skills are necessary for the adoption of blended learning. Based on the foregoing the study sought to investigate ICT skills of LIS educators for the adoption of blended learning in LIS education in Rivers State. Due to inadequate literature and lack of empirical evidence on ICT skills of LIS educators and the adoption of blended learning, this study sought to provide empirical evidence as well as more literature for researchers and LIS education.

\section{Objectives of the Study}

The main objective of the study is to assess ICT skills of LIS educators for the adoption of blended learning in Rivers State. The specific objectives are to:

1. identify the basic computer skills of LIS Educators for the adoption of blended learning in library schools in Rivers State

2. determine the mobile technology skills of LIS Educators for the adoption of blended learning in library schools in Rivers State

3. ascertain the possession of new media technology skills of LIS educators for the adoption of blended learning in Library schools in Rivers State

4. find out how blended learning has been adopted by LIS educators in Library schools in Rivers State.

5. unravel the challenges facing the adoption of blended learning in Library schools in Rivers state

\section{Research questions}

1. What are the basic computer skills possessed by LIS educators for the adoption of blended learning?

2. What are the mobile technology skills possessed by LIS educators for the adoption blended learning?

3. what are the new media skills possessed by LIS educators for the adoption of blended learning? 
4. How is blended learning being adopted by LIS educators?

5. what are the challenges facing LIS educators on the adoption of blended learning?

\section{Literature review}

Computer is an electronic machine or device that accepts data, processes data, stores data and retrieves data. Computer skills are a prerequisite for blended learning. Enwanta and Nwalo (2013) see computer skills as the comfort level with the use of computer operations and applications. Ojiebge (2010) in his study on ICT competencies of library staff in the University of Abuja and University of Jos adopted a research survey design. Questionnaire was used to gather the data which were analyzed using percentages and mean scores. It was discovered that many library staff could perform basic computer operations such as Microsoft word based tasks like typing and printing of documents as well as internet fundamentals. Basic computer skills are necessary for LIS educators to partake in blended learning. Therefore, LIS educators are expected to be proficient in the use of computer to teach students via zoom, skype, facebook, whatsapp or any other media they may find appropriate. They should be proficient in page formatting, uploading and downloading of documents or course materials via the internet

Mobile technologies are the portable and mostly handheld technologies usually powered by battery and compatible with wireless connectivity. It comprises devices that allow internet connection and communication such as smart phones, PC tablet and laptops. Palmer (as cited in Onuoha, 2019) observed that the availability of internet connectivity and mobile technological tools like digital camera and smart phone has made video streaming possible. According to him video streaming has enabled higher education institutions overseas to implement globalization strategy of reaching out to wider students without regional barriers. Rajkoomar (2013) found that most students were able to access e-classroom, blogs and podcasts from their work place on campus via their mobile phones. LIS educators need to be skilled in the use of mobile technologies in order to use it perform various online activities such access the web, interact with students and use it to deliver lecture.

New media technologies are trendy technologies that facilitate interaction, communication and collaboration. They include Facebook, Twitter, Onedrive and Google Doc. Rajkoomar (2013) ascertained that new media technologies like the blogs proved to be valuable communication tools as messages could be sent easily to all students. Abdullahi, Gora and Mohammed (2018) investigated the awareness and utilisation of new media technologies on library and information services in federal university of technology Minna. Correlational research design was used with a population of thirty-one librarians. Questionnaire was used to collect data. Descriptive statistics was used to analyse the demographic information and the research questions and inferential statistics of Pearson Product Moment Correlation was used to test the hypothesis at 0.5 level of significance. The result showed that facebook, twitter, whatsapp, blogs and dropbox had means scores above the criterion mean of 2.5 which implied that librarians were using the identified new media technologies. The emergent of new media has eased the stress in the adoption of blended learning therefore, LIS educators need to exploit new media technologies such as googledoc for collaboration, onedrive for digital preservation social media tools for interaction and lecture delivery.

The inability of most institutions in Nigeria to deploy state of the art infrastructures that will facilitate online learning has left educators to device means to teach students online. Some preferred to give students assignment via online forums and communicate or deliver lecture to students via various social media platforms. Kleinveldt, Schutte and Stilwell (2016) investigated how Cape Peninsula University of Technology (CPUT) libraries contributed to knowledge management processes using the 
Learning Management System, Blackboard, by embedding the librarian in the learning environment to support blended learning. Structured interviews were conducted at CPUT with eight lecturers involved in the Extended Curriculum Programme (ECP) in Faculty A and with one Faculty A librarian. It was discovered that lecturers used various teaching methods to support students. It was also found that although lecturers and the librarian thought that Blackboard improved student learning, both were aware of other means of reaching the students online such as Facebook or Google. Gibbs (2015) in his study on lecturers' research methods in institutions of higher learning in United Kingdom (UK) revealed that video use was common among LIS-professionals. Creating videos was one of the ways in which LIS educators through ICT could package information to meet the different ways in which their students consume information and also the information needs of distant students. LIS educators should work out modalities and leverage various ICT tools that facilitate blended learning. They could use zoom, skype, give and receive assignment via online, use interactive boards, etc.

LIS education in Nigeria is faced with several challenges in the wake of new technology. Some of which impede the adoption of blended learning. Adebayo, Iwu-James, Olawoyin, and Fagbohun (2019) ascertained that traditional learning method was still prevalent in many developing countries. It was attributed to the factors that hindered the prevalence of blended learning to include lack of skills and course design. Igwela, Admoi and Nsirim (2019) in their study on collaborative technologies for knowledge sharing in sustaining LIS education in Nigeria adopted a descriptive survey design. Data were collected using a structured questionnaire self-administered to the library educators. Data were analyzed using frequency distribution and simple percentages. It was discovered that the factors affecting LIS educators included lack of policy and guide and lack of cooperation among staff. LIS educators are mentors and role models to students. They contribute immensely to education and academic achievement of students. Lacking ICT skills, poor course design and curriculum, lack of policy and guide as well as lack of cooperation among them are threat to quality education. They are therefore expected to redress the challenges affecting them in contributing to quality education.

Literatures have been reviewed on ICT skills and specifically on basic computer skills, mobile technology skills and new media skills as well as strategies and challenges affecting the adoption of blended learning. In the course of the review, most literatures were on general ICT skills. Little empirical evidence exist specifically on basic computer skills, mobile technology skills and new media skills and no study was particularly done on the "Assessment of ICT skills and Adoption of Blended Learning by LIS Educators in Rivers State". This study therefore sought to fill the gap by providing more literature and empirical evidence.

\section{Methodology}

The study adopted a descriptive survey design, with a population of 45 ; census sampling technique was adopted to sample all the 45 library educators in four library schools in Rivers State namely University of Port Harcourt, Rivers State University, Ignatius Ajuru University of Education and Captain Elechi Amadi Polytechnic Library Schools as shown in the table 1 below

Table 1: Distribution of Population

\begin{tabular}{lll}
\hline Institutions & Population & sample \\
\hline University of Port Harcourt & 16 & 16 \\
Rivers State University & 15 & 15 \\
Ignatius Ajuru University of Education & 9 & 9 \\
Captain Elechi Amadi Polytechnic & 5 & 5 \\
Total & $\mathbf{4 5}$ & $\mathbf{4 5}$ \\
\hline
\end{tabular}


A structured questionnaire was used to gather data for the study. Out of 45 copies questionnaire administered, 42 copies of the instrument were returned and found valid for analysis. The data were analyzed using mean scores and percentages. It used a four-point scale of: Strongly Agree (SA) = 4points; Agree $(\mathrm{A})=3$ points; Disagree $(\mathrm{D})=$ and Strongly Disagree $(\mathrm{SD})=1$ point.

Decision Rule: Based on the mean of 2.5, the decision was that any item with a mean of 2.5 and above was accepted while any item with a mean below 2.5 was rejected.

\section{Findings}

Research question one: What are the basic computer skills possessed by LIS educators for the adoption of blended learning?

\section{Table 2: Basic Computer Skills of LIS Educators}

\begin{tabular}{lll}
\hline How can you perform the following basic computer tasks? & Mean & Decision \\
\hline Page formatting & 3.2 & Accept \\
Save and retrieve files/documents from the computer & 3.6 & Accept \\
Internet fundamental & 3.4 & Accept \\
Use computer in e-learning & 2.7 & Accept \\
Use computer to generate and post content online & 2.9 & Accept \\
Grand Mean & 3.1 & Accept \\
\hline
\end{tabular}

Table 2 shows the basic computer skills of LIS educators and reveals that all the items scored above the reference mean of 2.5 therefore are accepted that LIS educators are skilled in the use of basic computer operations. The grand mean of 2.8 indicates that LIS educators can use basic computer interfaces.

Research question two: What are the mobile technology skills possessed by LIS educators for the adoption of blended learning?

\section{Table 3: Mobile Technology skills of LIS educators}

\begin{tabular}{llll}
\hline How would you agree or disagree on the use of mobile technology on the following? & Mean & Decision \\
\hline Use mobile devices such as mobile phone, tablets, laptops, etc to make conference & 3.7 & Accept \\
video call & & & Accept \\
Use mobile technology to engage students on online courses & 3.4 & Accept \\
Use mobile technology to communicate using social media platforms & 3.5 & Accept \\
Use mobile technology to access the web. & 3.5 & Accept \\
Use mobile technology to upload and download documents such as lecture materials & 2.8 & \\
and students assignments & 3.4 & Accept \\
Grand Mean
\end{tabular}

Table 3 shows mobile technology skills of LIS educators and reveals all the items are above the reference mean of 2.5 showing that LIS educators in Rivers State accepted the fact that they were skilled in the use of mobile technology. The grand mean of 3.4 indicates that LIS educators are skilled in the use of mobile technologies. 


\section{Research question three: What are the new media skills possessed by LIS educators?}

Table 4: New Media Technology skills of LIS Educators

\begin{tabular}{lll}
\hline How skilled are you on the use of the following new media & & \\
technologies? & 2.3 & Reject \\
\hline Drop box & 2.9 & Accept \\
Zoom & 2.4 & Reject \\
Google Doc. & 2.7 & Accept \\
Skype & 3.7 & Accept \\
Facebook & 2.7 & Accept \\
Twitter & 2.8 & Accept \\
Grand Mean & \\
\hline
\end{tabular}

Table 4 shows the mean scores of LIS educators on new media skills and reveals that LIS educators accepted being skilled in the use facebook (3.7), zoom (2.9), Skype (2.7) and twitter (2.7) respectively. On the other hand, GoogleDoc (2.4) and dropbox (2.3) were poorly used by LIS educators. The grand mean of 2.8 indicates that LIS educators are skilled in the use of new media technologies.

\section{Research question four: How are LIS educators adopting blended learning?}

Table 5: Blended learning are being adopted by LIS educators

\begin{tabular}{|c|c|c|c|c|}
\hline How are you adopting blended learning in LIS education? & SA & A & $\mathrm{D}$ & SD \\
\hline Engage students on e-learning as complement to traditional learning & $2(5 \%)$ & $10(24 \%)$ & $19(45 \%)$ & $11(26 \%)$ \\
\hline $\begin{array}{l}\text { Promotes paperless study by giving and receiving assignments via } \\
\text { electronic means as complement to traditional learning }\end{array}$ & $5(12 \%)$ & $11(26 \%)$ & $16(38 \%)$ & $10(24 \%)$ \\
\hline Use of digital/interactive board in teaching & $2(5 \%)$ & $7(17 \%)$ & $20(48 \%)$ & $13(31 \%)$ \\
\hline Use of projector in teaching & $3(7 \%)$ & $9(21 \%)$ & $21(50 \%)$ & $9(21 \%)$ \\
\hline Engage students on workshops on e-learning & $2(5 \%)$ & $5(12 \%)$ & $22(53 \%)$ & $12(28 \%$ \\
\hline
\end{tabular}

$\mathrm{N}=42$. Strongly Agree (SA) + Agree (A) = Agree, Strongly Disagree + Disagree (D) = Disagree

Table 5 shows how LIS educators were adopting blended learning. Using a 4point likert scale (4-1) of Strongly Agree, Agree, Disagree and Strongly Disagree which were merged to Agree and Disagree, the result shows that LIS educators were not engaging students on workshop on e-learning (83\%), were not using digital/interactive board (78\%), were not using projector in teaching (72\%), were not engaging students in e-learning (71\%) and were not promoting paperless study (63\%) by giving and receiving assignments via electronic form such as CD-Rom, Email, yahoo-groups, Google-groups as a way of complementing traditional learning

\section{Research question five: What are the challenges affecting the adoption of blended learning}

Table 6 Challenges Facing the Adoption of Blended Learning

\begin{tabular}{|c|c|c|c|c|}
\hline $\begin{array}{l}\text { What are the Challenges LIS educators facing in the adoption of Blended } \\
\text { Learning }\end{array}$ & SA & A & $\mathbf{D}$ & SD \\
\hline Lack of facilities such as digital board, projector, computers, & $13(31 \%)$ & $18(43 \%)$ & $8(19 \%)$ & $3(7 \%)$ \\
\hline Resistance of students to adopt blended learning & $5(12 \%)$ & $18(43 \%)$ & $11(26 \%)$ & $8(19 \%)$ \\
\hline Resistance of staff to adopt blended learning & $11(26 \%)$ & $19(45 \%)$ & $9(21 \%)$ & $3(8 \%)$ \\
\hline Lack of skills on the part of the staff & $10(24 \%)$ & $16(38 \%)$ & $10(24 \%)$ & $6(14 \%)$ \\
\hline Lack of skills on the part of the students & $13(31 \%)$ & $14(33 \%)$ & $9(21 \%)$ & $6(14 \%)$ \\
\hline Lack of policy framework & $15(36 \%)$ & $17(40 \%)$ & $8(19 \%)$ & $2(5 \%)$ \\
\hline
\end{tabular}


Table 6 shows the challenges that faced LIS educators in the adoption of blended learning and reveals that lack of policy (76\%), lack of facilities (74\%), resistance of staff to adopt blended learning in LIS education (71\%), lack of skills on the part of the students $(64 \%)$, lack of skills on the part of the staff (62\%) and resistance of students to adopt blended learning (55\%) were the challenges affecting the adoption of blended learning in LIS education in Rivers State.

\section{Discussion of Findings}

On research question one, LIS educators were asked to identify their basic computer skills, the result shows that all the items were above the reference mean implying that LIS educators in Rivers State were skilled in saving and retrieving of document from the computer, page formatting, use computer to generate and post contents online and use computer in e-learning. The study is in agreement with the study carried out by Nsirim (2020) on Librarians' ICT competencies and utilisation of emerging technologies in academic libraries in Rivers State and found the possession of basic computer skills, page formatting, word processing and use of the toolbar, ability to navigate the various toolbars and internet fundamental.

On research question two, LIS educators were asked to determine their mobile technology skills. It revealed that all the items were above the reference mean of 2.5 showing that LIS educators in Rivers State accepted the fact that they were skilled in the use of mobile technology. It can therefore be stated that LIS educators could use mobile technologies to engage students on online courses, communicate using social media platforms, upload and download lecture documents. The result is in line with that of Sarfo, Amankwah, Oti-Agyen \& Yidana (2016) who studied information and communication technology access and use and competency level among second-cycle school teachers in Ghana and found that most of the respondents used mobile phones.

On research question three, LIS educators were asked to confirm their new media skills. It was revealed that LIS educators accepted being skilled in the use facebook, zoom, Skype and twitter. On the other hand, GoogleDoc was poorly used by LIS educators. This implies that LIS educators could use new technologies to engage students in online learning in complementing traditional learning. The study is in line with Abdullahi, Gora \& Mohammed (2018) on the awareness and utilisation of new media technologies on library and information services in federal university of technology Minna and found that facebook, twitter, whatsapp, blogs and dropbox had means scores above the criterion mean of 2.5 which showed that they utilised the new media identified above

On research question four LIS educators were asked on how they were adopting blended learning, the result shows that LIS educators were not engaging students on workshop on e-learning, were not using digital/interactive board, were not using projector in teaching, were not engaging students in elearning and were not promoting paperless study by giving and receiving assignments via electronic form such as CD-Rom, Email, yahoo-groups, Google-groups as a way of complementing traditional learning. The study disagrees with a study conducted by Igwela and Nsirim (2019) on collaborative technologies for knowledge sharing in sustaining LIS education in Nigeria: a survey of library schools in Rivers State and found that the library school management was putting up strategies to promote collaborative technologies.

On research question five, LIS educators were asked of the challenges faced in the adoption of blended learning, it was found that the challenges that were affecting LIS educators in Rivers State in the adoption of blended learning were Lack of facilities, resistance of staff to adopt blended learning in LIS education, lack of skills on the part of the staff, lack of skills on the part of the students, lack of policy and 
resistance on the part of the students. The study corroborate Igwela, Adomi and Nsirim (2019) who found lack of policy and guide, Lack of computer and other ICT gadgets, and lack of skilled staff among others were the factors affecting LIS educators in Rivers State and also agrees with Adebayo et al (2019) that library should play an active role in drafting and providing a clear, concise and friendly policy for the use of ICT in learning and teaching in the institution.

\section{Conclusion}

Academic environment is full of innovations and creativities and the emergence of ICT has greatly influenced the educational system. As the traditional system is becoming less effective due to the paradigm shift to a more collaborative and self-learning system, several innovations emerged like the blended learning which combines both the traditional and the e-learning. Library and information science education has taken this opportunity by leveraging blended learning in LIS education. However, due to its ICT driven, it requires ICT skills and library educators are expected to be skilled in the use of technologies that aid the exploitation of blended learning. The study therefore assessed ICT skills of LIS educators for the adoption of blended learning and showed that although LIS educators were skilled in the use of basic computer routines, mobile technologies and new media technologies, they were reluctant in the adoption of blended learning with their challenges including lack of skills and facilities.

\section{Recommendations}

Based on the findings of the study, it was recommended that:

1. LIS educators should utilise their ICT skills such as basic computer skills, mobile technology skills and new media skills to initiate and exploit blended learning in LIS education in Rivers State

2. LIS educators should leverage several technologies such as zoom, skype, facebook, whatsapp, etc in teaching and learning

3. LIS educators should participate in workshops and carry students along to fully exploit blended learning

4. Librarians' Registration Council of Nigeria should formulate a policy that will motivate and guide the use of blended learning in LIS education.

\section{References}

Adebayo , O., Iwu-James, J., Olawoyin , O.R., \&Fagbohun, M. (2019) Blended learning in higher education: implication and strategies for academic library support. Proceedings of INTED2019 Conference, Valencia, Spain. 7210-7217

Abdullahi,Z.M, Gora, A.L. \& Mohammed, A. (2018) Awareness and utilisation of new media technologies on library and information services in federal university of technology Minna. Nigerian Libraries: Journal of Nigerian Library Association, 51(2), 167-175

Agarwal, P. (2015). Next two decades of higher education: a developing countries perspective. International Higher Education, (80), 3. Retrieved from https://ejournals.bc.edu/ojs/index.php/ihe/article/view/6128

Alonge, A.J. (2018) Blended learning - fusing library and educational technology.

AFLIA African Libraries, Challenge to the World. IFLA Council and General Conference. Jerusalem: Israel, 13th-18, August. Age. A bimonthly report. No.226 
Babalola, A., Tsado L.Y., Udoudoh, S. J.,Uno' C. A., Madaki A.M. (September,2019) empowering LIS educators with ICT skills for creative and innovative knowledge sharing in the digital age. A paper presented at the $21^{\text {st }}$ National Conference/AGM of National Association of Library and Information Science Educators (NALISE), Ignatius Ajuru University of Education, Port Harcourt, Rivers State.

Bryan, A \&Volchenkova, K.N. (2016)Blended learning: definition, models, implications for higher education. Bulletin of the South Ural State University. 8(2) pp. 24-30

Chew E., Jones N., Turner D. (2008) Critical review of the blended learning models based on Maslow's and Vygotsky's Educational Theory' in Hybrid Learning and Education. Berlin,Springer Verlag. pp. 40-53. doi:10.1007/978-3-540-85170-7_4

Delaney, J., Johnson, A., Johnson, T. \&Treslan, D. (2010). Students' perceptions of effective teaching in higher education. St. John's, NL: distance education and learning technologies: Retrieved December 14, 2019 fromhttp://www.uwex.edu/disted/conference

Dhiman, A.K. (2010)Evolving roles of library \& information Centres in E-Learning environment. World library and information congress: 76th IFLA general conference and assembly. Retrieved December 14, 2019 from http://www.ifla.org/en/ifla76

Doyle, A. (2019). Information and communications technology (ICT) skills. Retrieved December, 152019 from https://www.thebalancecareer.com/information-and-communicationstechno logy-skills-4580324

Friesen M. (2012) Defining blended learning. Retrieved December 14, 2019 from http://blogs.ubc.ca/

Gibbs, G. (2015). Innovative pedagogies Series: Video creation and reuse for learning in higher education. UK: Higher Education Academy

Graham C.R., Dziuban C.D. (2008) Blended learning environments. Handbook of Researchon Educational Communications and Technology.Mahwah, Lawrence Earlbaum. 269-276.

Igwela, J.N.B. \&Nsirim, O.(2018) Mobile social media as a facilitator of library services delivery in Nigeria: A case study of Rivers State. International Journal of Information Processing and Communication. 6(2). 346-355

Igwela, J.N.B. Adomi, E. \&Nsirim, O.(September 2019)Collaborative technologies for knowledge sharing in sustaining LIS education in Nigeria: a survey of library schools in Rivers State. A paper presented at the $21^{\text {st }}$ National Conference/AGM of National Association of Library and Information Science Educators (NALISE), Ignatius Ajuru University of Education, Port Harcourt, Rivers State

Kleinveldt, L.T., Schutte, M. \& Stilwell, C. (2016) Embedded librarianship and blackboard usage to manage knowledge and support blended learning at a South African university of technology. South African Journal of Library and Information Science. 82(1). 62-74

Kumar, N. B. 2017) Use of Information Communication Technology (ICT) and library operation: an overview proceedings: International Conference on Future Libraries: From Promises to Practices 2017. 45-56

Muthu, M., Sivaraman, P., Singh, K., (2015). LIS education: issues and challenges in the present era: Retrieved January 15, 2020 from https://digitalcommons.unl.edu/libphilprac/ 
Nsirim, O. (2020) Librarians' ICT competencies and the utilisation of emerging technologies in academic libraries in Rivers State. Unpublished master's dissertation submitted to the department of library and information science, Ignatius Ajuru University of Education, Port Harcourt, Rivers State.

Omiunu O. G. (2017). Paradoxical Modeling of the Negative Uses of ICT and their implications among secondary school students in Oyo State, Nigeria: A Phenomenographical analysistowards a Grounded Theory. Library Philosophy \& Practice, 1-32. Retrieved January 15, 2020 from http://search.ebscohost.com/login.aspx?direct=true \&db=llf \&AN=127910780\&site=ehost-live

Rajkoomar, M. (2013) Blended learning in library and information science education and training. Proceedings of the IATUL Conferences. Retrieved from http://docs.lib.purdue.edu/iatul/2013/papers/1

Saleh, A. (2012). Educators perspective on library education in Nigeria. Library philosophy and practice. Retrieved June 172019 from digitalcommons.unl.edu.

Sarfo, F.K., Amankwah, S.K., Oti-Agyen, P. \& Yidana, I. (2016) Information and communication technology access and use and competency level among second-cycle school teachers in Ghana. 8(5), pp.43-51

Saxena,A. \&Yadav, R.D. (2013). Impact of mobile technology on libraries: A descriptive study. International Journal of Digital Library Services. Issue

Staker H., Horn M.B. (2013) Classifying K-12 blended learning. Retrieved December 20, 2019 fromhttp://www.christenseninstitute.org/wp-content/uploads/2013/.

Sen, D. \&Sarmah, M. (2014) Blended learning solution for the LIS education: AU perspective 9th Convention planner-2014 Dibrugarh University, Assam, INFLIBNET Centre, Gandhinagar. $174-181$

Yamada, G. (2015). The boom in university graduates and the risk of underemployment. IZA World of Labor. https://doi.org/10.15185/izawol.16 